\title{
1 Optimisation of a throat downdraft gasifier for hydrogen production
}

2

3

4

5

6

7

8 Abstract

9 Gasification of coal is a well-known technology used to convert solid coal into gas
Phuet Prasertcharoensuk ${ }^{1}$, David A. Hernandez ${ }^{2}$, Steve J. Bull ${ }^{1}$ and Anh N. Phan ${ }^{1 *}$ ${ }^{1}$ School of Engineering, Newcastle University, Newcastle Upon Tyne, UK. ${ }^{2}$ Department of Virtual Analysis - Product Engineering FCA de México, Mexico City, Mexico.

*Corresponding authors: anh.phan@ncl.ac.uk (syngas). The implementation of gasification for waste and biomass still requires attention due to the difference in nature of biomass compared to coal. Although, modification to a gasifier is one of the main approaches to achieve high quality syngas production (high $\mathrm{H}_{2} / \mathrm{CO}$ ratio) and to eliminate tar formation, the effect of design of the gasifier has not been studied. Downdraft gasifiers are reported to produce relatively high quality syngas with low tar concentration compared to other designs. Therefore, in this study a $20 \mathrm{~cm}$ diameter throat downdraft gasifier was numerically optimised using Computational Fluid Dynamics modelling. The effect of throat diameter and the position of the air inlet nozzles above the throat on the properties of the gas and the temperature profile in the gasifier was systematically investigated and validated using experimental data. The throat diameter and the position of the air inlet nozzles had a significant effect on the properties of the gas and temperature profile. The modelling and experimental results agreed very well with less than $5 \%$ deviation. This confirms that the numerical approaches are valid and can be used in scaling up biomass gasification, reducing process development time from laboratory scales to pilot/industrial scales. The maximum concentration of H2 
25 (31.2\%mol) and highest $\mathrm{H} 2 / \mathrm{CO}$ ratio (1.25) was found at a ratio of throat diameter to gasifier diameter of 0.40 and the position of the air inlet nozzles at $10 \mathrm{~cm}$ above the throat.

27 Keywords: CFD model; Biomass gasification; Throat downdraft gasifier; Syngas

28

29

30

31

32

\section{Introduction}

Global primary energy demand is expected to increase by $48 \%$ by 2040 due to the rapid growth of population, urbanization and economic activity [1]. The majority of energy supply is currently reliant on conventional energy resources such as coal (21\%), petroleum (28\%) and natural gas (32\%) [2], which have negative environmental impacts i.e. greenhouse gas $\left(\mathrm{CO}_{2}\right)$ emissions, air pollution $\left(\mathrm{SO}_{x}, \mathrm{NO}_{\mathrm{x}}\right.$, particulates and toxic metals and other impurities) and land contamination [3]. Although, alternative energy sources (e.g. solar, hydro power, biomass, wind, geothermal and nuclear power) have been sought to reduce the dependency upon fossil fuels and reduce the environmental impact, the versatility of biomass makes it most attractive as it can be used to produce not only heat and electricity but also, chemicals and fuels for the transportation sector [4] (Figure 1). Biomass used for energy production is mostly from wood and waste wood (41\%), followed by agriculture residues (24\%), municipal solid waste (20\%) with a small portion of energy crops (15\%) [5]. 


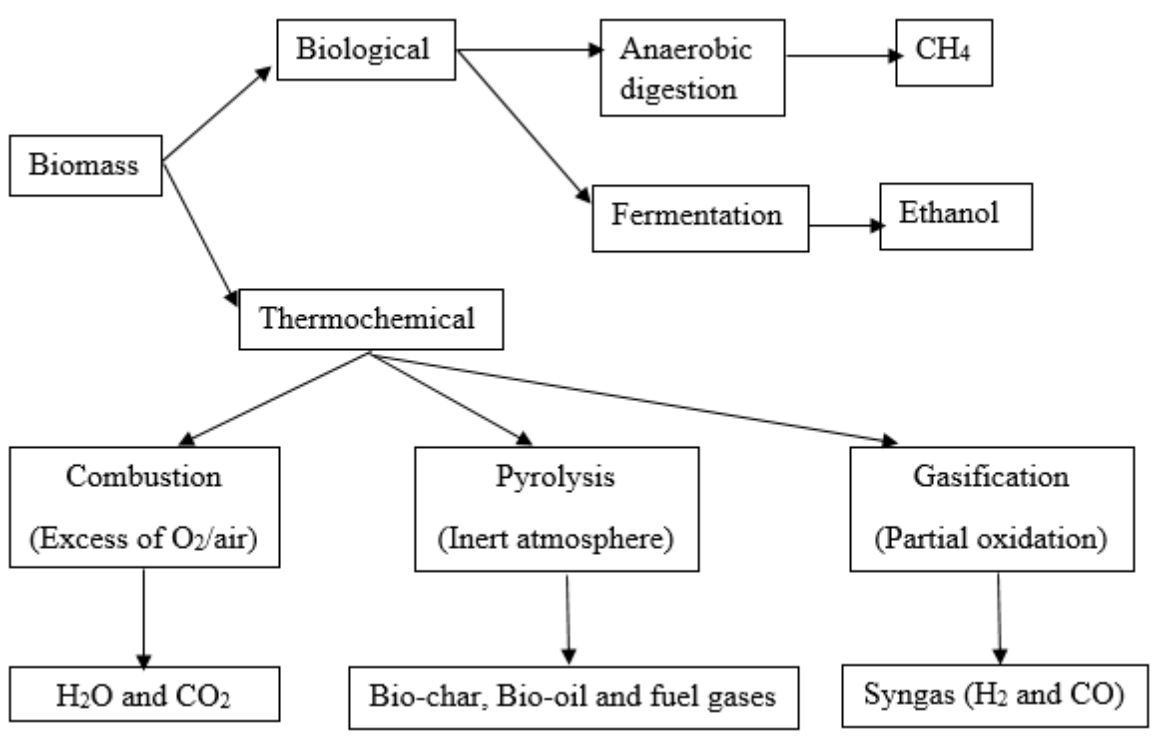

44 Figure 1: Biomass to bioenergy conversion pathways (adapted from Sharma et al. [6]) Gasification is a partial oxidation process to convert carbonaceous substances into a mixture of mainly $\mathrm{H}_{2}$ and $\mathrm{CO}$ (synthetic gas or syngas), with small amounts of $\mathrm{CH}_{4}, \mathrm{CO}_{2}$,

$47 \quad \mathrm{~N}_{2}$, char, ash, tar, oils in a temperature range of 973-1773 K [7]. The proportion of components in the syngas product is strongly influenced by the type of gasifier and its operating conditions such as choice of gasifying agent $\left(\mathrm{O}_{2}, \mathrm{CO}_{2}\right.$, air or steam), equivalence ratio of gasifying agent to feedstock and properties of the feedstock. Fixedbed gasifiers are the most common technology for small and medium scale biomass gasification due to their simplicity and low investment costs compared to fluidized bed and entrained flow gasifiers [8-10]. A downdraft gasifier is preferable in this study because it is known to produce high quality syngas, with low tar content $\left(0.015-3 \mathrm{~g} / \mathrm{Nm}^{3}\right)$ in the gas stream compared to that in an updraft gasifier (30-150 $\left.\mathrm{g} / \mathrm{Nm}^{3}\right)$ [11]. Tar is a complex mixture of condensable organic compounds from the products of gasification

57 containing primarily aromatic hydrocarbons [12-14]. The tar content influences performance of the gasification system, the quality of the product gas and creates 
operational difficulties for the downstream process (e.g. corrosion, clogging and fouling of installations) $[15,16]$.

Computational Fluid Dynamics (CFD) modelling has previously been used to predict the behaviour of biomass gasification to optimize operating conditions of an existing gasifier [17-29]. In general, only a few aspects of the gasifier design have been investigated in any one study. For instance, some CFD studies only focused on the effect of either (i) the number and angle of nozzles [17, 30, 31] or throat angle and nozzle inclination [32-34] on the performance of a throat downdraft gasifier. Very few workers have applied CFD models for studying interactions between various design aspects of a gasifier and operating conditions to propose a proper configuration of a throat downdraft gasifier for high quality of syngas production. In this study, the effect of the ratio of throat to gasifier body diameter and the position of the air inlet nozzles above the throat were numerically investigated using CFD, ANSYS FLUENT 16.1. It is essential to examine interactions between zones in the gasifier and inlet of a gasifying agent as these determine the quality of product gas. Furthermore, the synergetic effects of gasifier design and operating conditions in a throat downdraft gasifier should be investigated to provide a correlation between operating window and the design of a downdraft gasifier for biomass gasification. Either an Eulerian-Eulerian or Eulerian-Lagrange approach could be used to resolve gas and solid phases together with the conservation equations (momentum, mass and energy) and the standard k- $\varepsilon$ turbulence model for the gas phase. The EulerianLagrange approach can track individual particles inside the system so it is suitable to study particle size distributions, interactions of particles, mass and heat transfer between particles, and transient forces acting at the particle level [35, 36], therefore it is more suitable for the modelling of fluidized bed gasifiers. The main disadvantage of the 
83 Eulerian-Lagrange approach is it is very computationally time intensive when tracking a

84

85

86

87 large number of particle collisions coupled with chemical reactions [37]. In contrast, the Eulerian-Eulerian approach assumes both gas and solid as a second continuous phase and has been proven to effectively model for fixed-bed gasifiers [38-40] in order to predict the macroscopic characteristics of a given system with low computational time. As this study mainly focused on the gas phase for syngas production from a throat downdraft gasifier instead of characterising the particles inside the gasifier, the modified EulerianEulerian approach was chosen. The modelling was then validated using experimental data available in literature.

\section{Numerical model of a throat downdraft gasifier}

\subsection{Geometry and mesh construction}

A 3D model and the volume discretization of a $20 \mathrm{~cm}$ diameter and $55 \mathrm{~cm}$ long throat downdraft gasifier (Figure 2a) was created and meshed using DesignModeler (Figure 2b). The height of pyrolysis, oxidation and reduction zones were estimated at $15 \mathrm{~cm}, 10 \mathrm{~cm}$ and $30 \mathrm{~cm}$ respectively. Throat diameters of 5, 6, 8 and $10 \mathrm{~cm}$ were varied to obtain ratios of throat to gasifier diameter of $0.25-0.50$, with varying positions of the air inlet nozzles above the throat of 8,10 or $12 \mathrm{~cm}$ with the purpose of isolating the effect of both design parameters on the gas properties i.e. concentration and temperature profile. A mesh independence study was carried out at various node and cells counts and the model was built at the conditions where the solutions converged (Figure 2b). 


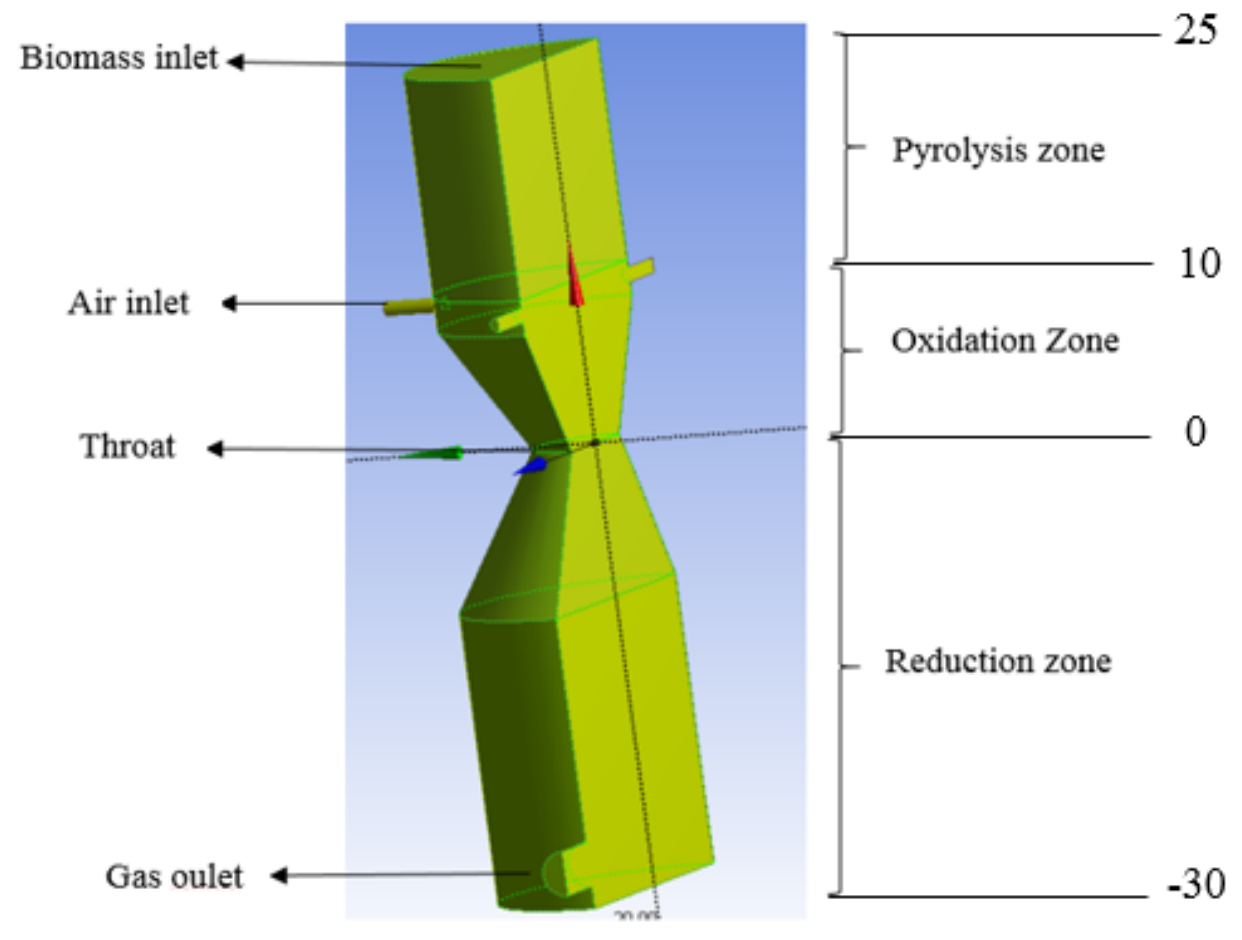

(a)

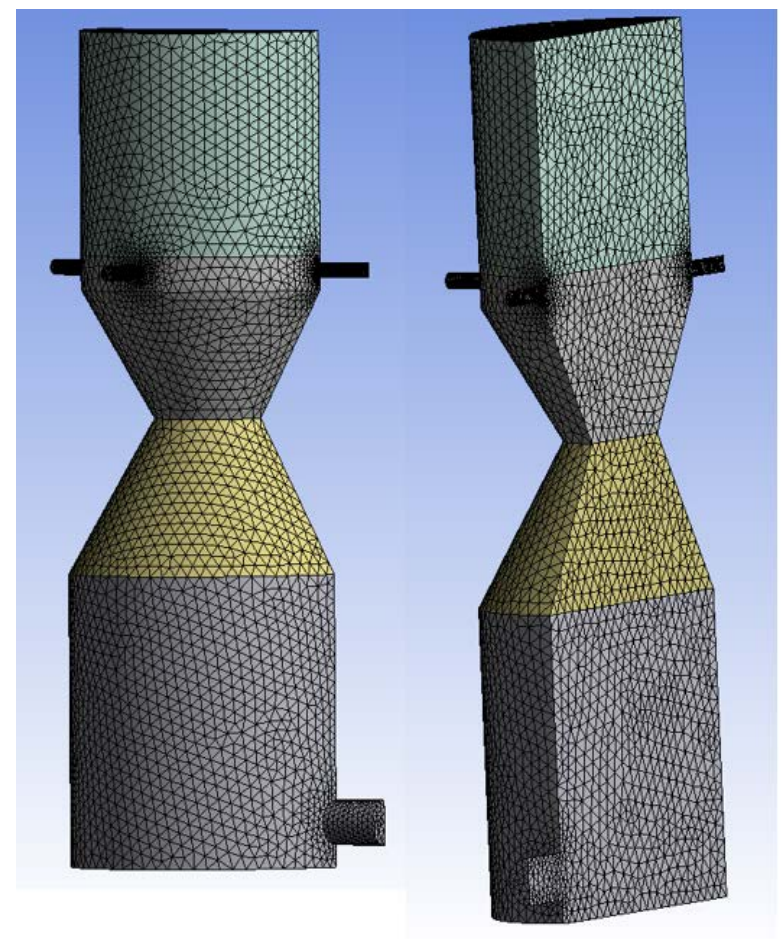

(b)

107 Figure 2: (a) Configuration of the throat downdraft gasifier; (b) Mesh model of the throat 108 downdraft gasifier. 


\subsection{Computational model}

110 Computational Fluid Dynamic (CFD) software, ANSYS FLUENT 16.1 was used for

111 numerical simulation in this study. The main objective of the CFD analysis was to obtain

112 accurate and reliable modelling results in a reasonable computational time to enable

113 design optimisation. The species transport solution is solved by using the pressure based

114 solver under gravitational acceleration. The Eulerian-Eulerian approach was used to solve transport phenomena, with the conservation of momentum, mass and energy equations.

The standard k- $\varepsilon$ model was used to capture the turbulence flow of the gas phase inside

117 the gasifier with the standard wall functions. The SIMPLE algorithm scheme was used to

118 solve the pressure-velocity coupling and the standard scheme was chosen for the pressure

119 discretization. The second order upwind scheme was implemented after grid independence studies were completed to obtain accurate results for other calculated variables.

122

\subsubsection{Model assumptions}

To simplify the simulation of a throat downdraft gasifier, the following assumptions were made:

- Atmospheric pressure.

- The gasifier was operated under steady state conditions.

- No heat loss through the vessel wall.

- No-slip boundary condition at the wall of the gasifier. The wall was assumed to be insulated and the heat flux at the wall was neglected.

- The wood feed rate was $1 \mathrm{kghr}^{-1}$ at a temperature of $400 \mathrm{~K}$ with the moisture content less than $10 \%$ wt. The drying zone was not included in the gasifier 

configuration but it was assumed that the feedstock would achieve moisture content $<10 \%$ wt when it reached the pyrolysis zone.

- The gasifying agent (air) was introduced through nozzles at $350 \mathrm{~K}$

- The ratio of the actual air/fuel to the stoichiometric air/fuel (ER ratio) was fixed at 0.25 .

\subsubsection{Governing equations}

\subsubsection{The momentum conservation equation}

139 The momentum equation based on the Newton's laws of motion, relates the sum of the 140 forces acting on a fluid element to its acceleration which is the rate of change of 141 momentum in the direction of the resultant force. The momentum conservation equation 142 can be written in the following form:

$143 \frac{\partial}{\partial t}(\rho \vec{v})+\nabla \cdot(\rho \vec{v} \vec{v})=-\nabla p+\nabla \cdot(\tau)+\rho \vec{g}+\vec{F}$

144 where $\rho$ is the static pressure, $\rho \vec{g}$ and $\vec{F}$ are the gravitational body force and external body 145 force respectively. The stress tensor $\tau$ in Equation 2.1 is defined by:

$146 \tau=\mu\left[\left(\nabla \vec{v}+\nabla \vec{v}^{T}\right)-\frac{2}{3} \nabla \cdot \vec{v} I\right]$

147 where I is the unity matrix and $\vec{v}^{T}$ is the transpose of $\vec{v}$

\subsubsection{The mass conservation equation}

149 The general form of the mass conservation equation, known as the continuity equation is 150 written as follows:

$151 \frac{\partial \rho}{\partial t}+\nabla \cdot(\rho \vec{v})=S_{m}$

152 where $S_{m}$ is the mass added to the continuous phase from the dispersed second phase. 


\subsubsection{The energy conservation equation}

154 The energy conservation is based on the first law of thermodynamics, the internal energy 155 gained by a system must be equal to the heat absorbed by the system minus work done 156 by the system. It can be written in the general form as follows:

$157 \quad \frac{\partial}{\partial t}(\rho E)+\nabla \cdot(\vec{v}(\rho E+p))=\nabla \cdot\left(k_{e f f} \nabla T-\sum_{j=1}^{N} h_{j} \vec{J}_{j}+(\tau \cdot \vec{v})\right)+S_{h}$

158 where $k_{\text {eff }}$ is the effective thermal conductivity ( $\mathrm{k}+\mathrm{k}_{\mathrm{t}}$, where $\mathrm{k}_{\mathrm{t}}$ is the turbulent thermal

159 conductivity). The first three terms of the right hand side of the Equation 2.4 represent

160 heat flux due to the conduction according to Fourier's law of conduction, species 161 diffusion and viscous dissipation due to normal shear stresses respectively. The total energy $\mathrm{E}$ in Equation 2.4 can be defined by:

$163 E=h-\frac{p}{\rho}+\frac{v^{2}}{2}$

164 where the enthalpy is defined as:

$165 \quad h=\sum_{j=1}^{N} Y_{j} h_{j}$

166 with $Y_{j}$ being the mass fraction of species $\mathrm{j}$ and

$167 \quad h_{j}=\int_{T_{r e f}}^{T} c_{p, j} d T$

168

169

170

171

172

174

where the value used for $\mathrm{T}_{\text {ref }}$ in the sensible enthalpy for the pressure-based solver is $298.15 \mathrm{~K}$

\subsubsection{Transport equation for standard k-epsilon}

The standard k- $\varepsilon$ model is one of the most used turbulence models in Computational Fluid Dynamics due to its robustness and reasonable accuracy for a wide range of flows. The k- $\varepsilon$ model is a semi empirical model based on transport equations for turbulent kinetic energy $\mathrm{k}$ and its dissipation rate $\varepsilon$. In the derivation of the model it is assumed that the 
175 flow is fully turbulent and the effects of molecular viscosity are negligible. The transport 176 equations for turbulent kinetic energy and its dissipation rate are defined as follow:

$177 \frac{\partial}{\partial t}(\rho k)+\frac{\partial}{\partial x_{i}}\left(\rho k u_{i}\right)=\frac{\partial}{\partial x_{j}}\left[\left(\mu+\frac{\mu_{t}}{\sigma_{k}}\right) \frac{\partial k}{\partial x_{j}}\right]+G_{k}+G_{b}-\rho \varepsilon-Y_{m}+S_{k}$

$178 \frac{\partial}{\partial t}(\rho \varepsilon)+\frac{\partial}{\partial x_{i}}\left(\rho \varepsilon u_{i}\right)=\frac{\partial}{\partial x_{j}}\left[\left(\mu+\frac{\mu_{t}}{\sigma_{\varepsilon}}\right) \frac{\partial \varepsilon}{\partial x_{j}}\right]+C_{1 \varepsilon} \frac{\varepsilon}{k}\left(G_{k}+C_{3 \varepsilon} G_{b}\right)-C_{2 \varepsilon} \rho \frac{\varepsilon^{2}}{k}+S_{\varepsilon}(2.9)$

179 where $S_{k}$ and $S_{\varepsilon}$ are the source terms for k and $\varepsilon$ respectively and $G_{k}$ is the term for the 180 production of turbulent kinetic energy due to the mean velocity gradient and the Reynolds 181 stress is defined as:

$182 G_{k}=-\rho \overline{u_{\imath}^{\prime} u_{\jmath}^{\prime}} \frac{\partial u_{j}}{\partial x_{i}}$

$183 G_{b}$ represents the generation of turbulent kinetic energy that arises due to buoyancy and 184 is defined as follows:

$185 G_{b}=\beta g_{i} \frac{\mu_{t}}{P r_{t}} \frac{\partial T}{\partial x_{i}}$

$186 Y_{M}$ represents the contribution of the fluctuating dilatation in compressible turbulence to 187 the overall dissipation rate and is defined as:

$188 Y_{M}=2 \rho \varepsilon M_{t}^{2}$

189 The turbulent viscosity $\left(\mu_{t}\right)$ is computed by combining the local values of turbulent 190 kinetic energy (k) and dissipation rate $(\varepsilon)$ at each point by:

$191 \mu_{t}=\rho C_{\mu} \frac{k^{2}}{\varepsilon}$

192 The values of $C_{1 \varepsilon}, C_{2 \varepsilon}, C_{\mu}, \sigma_{k}$ and $\sigma_{\varepsilon}$ in Equations 2.8 and 2.9 are constants and their

193 values for the standard k- $\varepsilon$ model are follows:

$194 C_{1 \varepsilon}=1.44, C_{2 \varepsilon}=1.92, C_{\mu}=0.09, \sigma_{k}=1.00$ and $\sigma_{\varepsilon}=1.30$ 
200

201

202

203

204

\subsubsection{Reactions model}

\subsubsection{The pyrolysis zone}

Pyrolysis is the thermochemical decomposition of feedstock to condensable and noncondensable gases and char, in the absence of oxygen/air at a temperature range of 473$773 \mathrm{~K}$ [41]. The overall pyrolysis decomposition can be described in Figure 3 below.

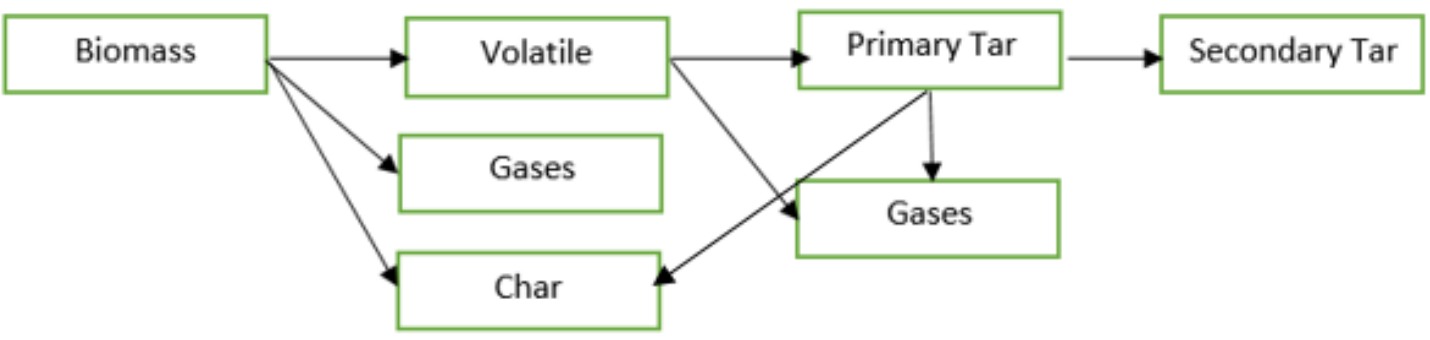

Figure 3: Reaction pathways in the pyrolysis stage (adapted from Fernando and Narayan [42])

There is limited kinetic reaction data available in the literature to represent the exact mechanisms of the pyrolysis process (Figure 3). This is mainly due to the large number of possible reactions occurring in the pyrolysis zone of which can generate tars. Tars are a complex mixture of condensable hydrocarbons containing single, multiple ring aromatic compounds with and without complex polycyclic aromatic hydrocarbons (PAHs) [4345]. A simple one-step global reaction model has been widely accepted to model the pyrolysis processes reactions developed by Di Blasi [46, 47] and Fernando et al. [48]. This model assumes that all the volatiles and tar compounds in the pyrolysis stage are instantaneously decomposed further into $\mathrm{CO}, \mathrm{CO}_{2}, \mathrm{CH}_{4}, \mathrm{H}_{2}$ and $\mathrm{H}_{2} \mathrm{O}$ compounds to simplify the model. Kinetic parameters for pyrolysis e.g. pre-exponential and activation energy was $1.00 \times 10^{8} \mathrm{~s}^{-1}$ and $140 \mathrm{kJmol}^{-1}$ respectively [19, 49]. 


\subsubsection{The oxidation zone}

215 The oxidation zone is where the reactions between char from the pyrolysis stage and the gasifying agent $\left(\mathrm{O}_{2}, \mathrm{CO}_{2}\right.$, air or steam) occur at a temperature between $1373-1773 \mathrm{~K}$ to

217 generate most of the $\mathrm{CO}, \mathrm{H}_{2} \mathrm{O}$ and $\mathrm{CO}_{2}$ [50]. Three main reactions in the oxidation zone are considered with their kinetic reaction rate parameters that were used in the model listed in Table 1.

$$
\mathrm{C}+\mathrm{O}_{2} \rightarrow \mathrm{CO}_{2}\left(\Delta \mathrm{H}=-394 \mathrm{kJkmol}^{-1}\right)
$$

$$
\mathrm{C}+\frac{1}{2} \mathrm{O}_{2} \rightarrow \mathrm{CO}\left(\Delta \mathrm{H}=-110 \mathrm{kJkmol}^{-1}\right)
$$

$$
\mathrm{H}_{2}+\frac{1}{2} \mathrm{O}_{2} \rightarrow \mathrm{H}_{2} \mathrm{O}\left(\Delta \mathrm{H}=-242 \mathrm{kJkmol}^{-1}\right)
$$

\subsubsection{The reduction zone}

In this zone the remaining residues and gaseous products from the pyrolysis and oxidation zones are converted into non-condensable gases $\left(\mathrm{H}_{2}, \mathrm{CO}, \mathrm{CO}_{2}, \mathrm{CH}_{4}\right)$ in a temperature range of 973-1273 $\mathrm{K}$ including both heterogeneous and homogeneous reactions $[7,8]$.

Five reactions are considered in the reduction zone as follows and the kinetic reaction rate parameters used in the model are listed in Table 1.

$$
\mathrm{C}+\mathrm{CO}_{2} \rightarrow 2 \mathrm{CO}\left(\Delta \mathrm{H}=+172 \mathrm{kJkmol}^{-1}\right) \quad \text { (Boudouard reaction) }
$$

$\mathrm{C}+\mathrm{H}_{2} \mathrm{O} \rightarrow \mathrm{CO}+\mathrm{H}_{2}\left(\Delta \mathrm{H}=+131 \mathrm{kJkmol}^{-1}\right)$ (steam reforming reaction)

$\mathrm{C}+2 \mathrm{H}_{2} \rightarrow \mathrm{CH}_{4}\left(\Delta \mathrm{H}=-74.8 \mathrm{kJkmol}^{-1}\right)$ (hydrogenation reaction)

$$
\mathrm{CH}_{4}+\mathrm{H}_{2} \mathrm{O} \rightarrow \mathrm{CO}+3 \mathrm{H}_{2}\left(\Delta \mathrm{H}=+206 \mathrm{kJkmol}^{-1}\right) \text { (steam reforming reaction) }
$$

$$
\mathrm{CO}+\mathrm{H}_{2} \mathrm{O} \rightarrow \mathrm{CO}_{2}+\mathrm{H}_{2}\left(\Delta \mathrm{H}=-41.2 \mathrm{kJkmol}^{-1}\right) \text { (water-gas shift reaction) }
$$

\subsubsection{Boundary conditions and solution methods}

It was assumed that waste wood was fed from the top of the gasifier at a constant rate of $1 \mathrm{kghr}^{-1}$ at a temperature of $400 \mathrm{~K}$ (Figure 2). The model assumed that the waste wood passed through the drying zone, which was separated from the configuration of the 
238 downdraft gasifier setup in Figure 2. The assumption is accepted as in reality feedstock 239 must be dried to a certain moisture content before feeding into a gasifier. The 240 physiochemical characteristics of the wood were experimentally determined and the 241 kinetic parameters in the gasification process were adapted from literature values. The 242 gasifying agent (air) was preheated to $350 \mathrm{~K}$ and then introduced into the gasifier through 243 four inlet nozzles, which are located at the middle part of the gasifier (Figure 2a) at a 244 fixed ratio of the actual air/fuel to the stoichiometric air/fuel (ER ratio) of 0.25 . The 245 numerical methods and boundary conditions used in this model are shown in Table 1.

246 Table 1: Parameters used for modelling a throat downdraft gasifier

\begin{tabular}{|c|c|}
\hline \multicolumn{2}{|l|}{ Properties of wood } \\
\hline Proximate analysis & Values (\%wt, dry basis) \\
\hline Volatile matter & 84.12 \\
\hline Fixed carbon & 15.37 \\
\hline Ash & 0.51 \\
\hline Ultimate analysis & Values (\%wt, dry basis) \\
\hline $\mathrm{C}$ & 41.80 \\
\hline $\mathrm{H}$ & 6.39 \\
\hline $\mathrm{O}$ & 51.50 \\
\hline $\mathrm{N}$ & 0.32 \\
\hline Low heating value $\left(\mathrm{MJkg}^{-1}\right)$ & 15.27 \\
\hline High heating value $\left(\mathrm{MJkg}^{-1}\right)$ & 17.69 \\
\hline The empirical formula of wood & $\mathrm{C}_{6.00} \mathrm{H}_{10.50} \mathrm{O}_{5.00} \mathrm{~N}_{0.05}$ \\
\hline
\end{tabular}




\begin{tabular}{|c|c|c|c|}
\hline \multicolumn{2}{|c|}{ Reaction } & $\begin{array}{c}\text { Pre- } \\
\text { exponential } \\
\text { factor }\left(\mathrm{s}^{-1}\right)\end{array}$ & $\begin{array}{l}\text { Activation } \\
\text { energy } \\
\left(\mathrm{kJmol}^{-1}\right)\end{array}$ \\
\hline \multicolumn{2}{|c|}{ Biomass $\rightarrow$ Char + ash } & $1.00 \times 10^{8}$ & $1.40 \times 10^{2}$ \\
\hline \multicolumn{2}{|c|}{$\mathrm{C}+\mathrm{O}_{2} \rightarrow \mathrm{CO}_{2}$} & $5.67 \times 10^{9}$ & $1.60 \times 10^{2}$ \\
\hline \multicolumn{2}{|c|}{$\mathrm{C}+\frac{1}{2} \mathrm{O}_{2} \rightarrow \mathrm{CO}$} & $7.92 \times 10^{4}$ & $2.18 \times 10^{2}$ \\
\hline \multicolumn{2}{|c|}{$\mathrm{H}_{2}+\frac{1}{2} \mathrm{O}_{2} \rightarrow \mathrm{H}_{2} \mathrm{O}$} & $3.53 \times 10^{8}$ & $3.05 \times 10^{1}$ \\
\hline \multicolumn{2}{|c|}{$\mathrm{C}+\mathrm{CO}_{2} \rightarrow 2 \mathrm{CO}$} & $5.89 \times 10^{2}$ & $2.23 \times 10^{2}$ \\
\hline \multicolumn{2}{|c|}{$\mathrm{C}+\mathrm{H}_{2} \mathrm{O} \rightarrow \mathrm{CO}+\mathrm{H}_{2}$} & 5.71 & $6.58 \times 10^{1}$ \\
\hline \multicolumn{2}{|c|}{$\mathrm{C}+2 \mathrm{H}_{2} \rightarrow \mathrm{CH}_{4}$} & $1.00 \times 10^{11}$ & $4.20 \times 10^{1}$ \\
\hline \multicolumn{2}{|c|}{$\mathrm{CH}_{4}+\mathrm{H}_{2} \mathrm{O} \rightarrow \mathrm{CO}+3 \mathrm{H}_{2}$} & $7.30 \times 10^{1}$ & $3.62 \times 10^{1}$ \\
\hline \multicolumn{2}{|c|}{$\mathrm{CO}+\mathrm{H}_{2} \mathrm{O} \rightarrow \mathrm{CO}_{2}+\mathrm{H}_{2}$} & $3.00 \times 10^{-2}$ & $6.58 \times 10^{1}$ \\
\hline \multicolumn{4}{|l|}{ Boundary conditions } \\
\hline Zone & Boundary type & Value & $\begin{array}{c}\text { Temperature } \\
\text { (K) }\end{array}$ \\
\hline Air inlet & Velocity inlet & $1.73 \mathrm{~ms}^{-1}$ & 350 \\
\hline Biomass inlet & Mass flow inlet & $2.77 \times 10^{-4} \mathrm{kgs}^{-1}$ & 400 \\
\hline Gas outlet & Pressure outlet & $0 \mathrm{~Pa}$ & 700 \\
\hline Symmetry & Symmetry & - & - \\
\hline Gasifier wall & Wall & $0 \mathrm{Wm}^{-2}$ & - \\
\hline
\end{tabular}




\begin{tabular}{|c|c|}
\hline Solution methods & \\
\hline Pressure-Velocity Coupling & SIMPLE \\
\hline Gradient & Least Squares Cell Based \\
\hline Pressure & Standard \\
\hline All other parameters & Second Order Upwind \\
\hline Solution Controls & \\
\hline Under-Relaxation Factors & \\
\hline Pressure & 0.3 \\
\hline Density & 1 \\
\hline Body Forces & 1 \\
\hline Momentum & 0.7 \\
\hline Turbulent Kinetic Energy & 0.8 \\
\hline Turbulent Dissipation Rate & 0.8 \\
\hline Turbulent Viscosity & 1 \\
\hline Energy & 1 \\
\hline Temperature & 1 \\
\hline Mean Mixture Fraction & 1 \\
\hline Mixture Fraction Variance & 0.9 \\
\hline Discrete Phase Sources & 0.5 \\
\hline Solution Initialization & \\
\hline Initialization Method & Hybrid Initialization \\
\hline Run Calculation & \\
\hline Number of Iterations & 1500 \\
\hline
\end{tabular}


247

\section{Results and discussion}

\subsection{Effect of throat to gasifier diameter: modelling results and validation}

\subsubsection{Syngas composition}

The formation of syngas in the throat downdraft gasifier with a throat diameter 5, 6, 8 and $10 \mathrm{~cm}$ (or ratios of throat to gasifier diameter of $0.25-0.50$ ) at a fixed position of the air inlet nozzles at $10 \mathrm{~cm}$ above the throat is illustrated in Figure 4. The results showed that the throat diameter had a significant impact on the formation of syngas across the throat downdraft gasifier. The $\mathrm{H}_{2}$ and $\mathrm{CO}$ formation was high in the reduction zone (28-31\%mol $\mathrm{H}_{2}$ and $25-32 \%$ mol CO) compared to that in pyrolysis and oxidation zones. This is due to the Boudouard (R-4), water gas (R-5) and steam-reforming (R-7) reactions occurring in this zone. The $\mathrm{CO}_{2}$ concentration was low in the pyrolysis zone $(5-11 \% \mathrm{~mol})$ but increased to $21-27 \%$ mol in the oxidation zone. This increase is due to the combustion of volatiles and char (R-1) and others. A decrease in $\mathrm{CO}_{2}$ in the reduction zone to $14 \%$ mol could be due to the Boudouard reaction (R-4). The $\mathrm{CH}_{4}$ concentration was maximised in the pyrolysis zone at $17-18 \%$ mol and further reduced in the oxidation and reductions zones to $3-5 \%$ mol, due to the steam-reforming reaction (R-7).

A uniform formation of syngas across the throat downdraft gasifier was observed at a ratio of throat diameter to gasifier diameter of 0.40 (Figure 4c). This is due to a good proportion of the ratio of throat diameter to gasifier diameter and the air velocity inlet, resulting in well-mixed volatiles and gasifying agent (air) which produced uniform concentration of product gas across the throat downdraft gasifier. This sizing of the gasifier also enhanced temperature uniformity in the oxidation zone (Figure 6c). High and uniform temperature (1800-2000 K) in the oxidation zone could eliminate the tar formation in the gas stream to achieve high quality of syngas production. The main syngas 

at $10 \mathrm{~cm}$ above the throat is illustrated in Table 2.

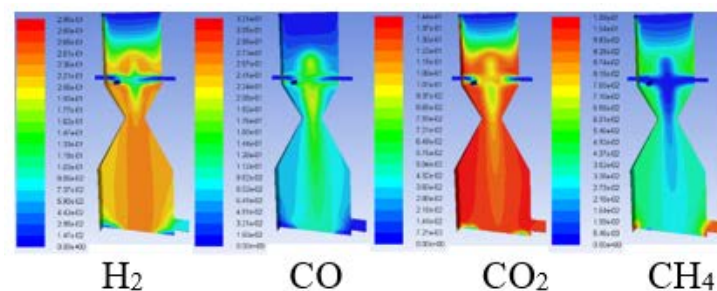

(a)

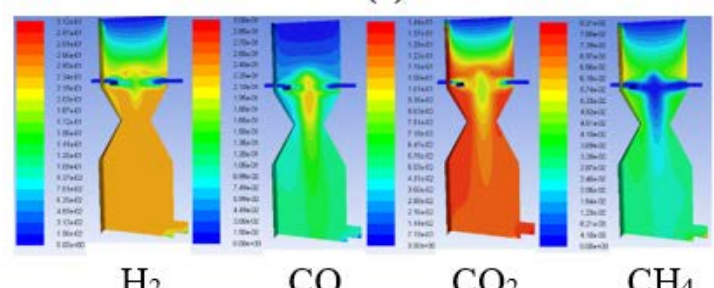

(c)

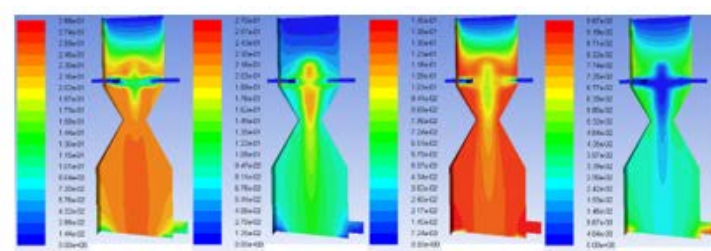

$\mathrm{H}_{2}$

$\mathrm{CO}$

$\mathrm{CH}_{4}$

(b)

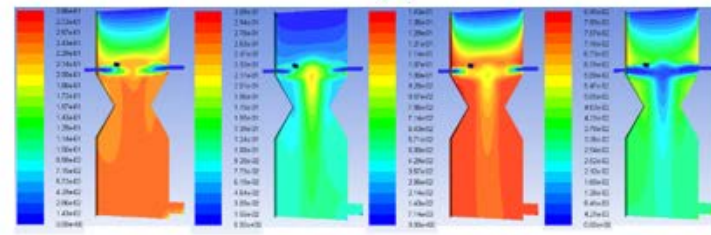

$\mathrm{H}_{2}$

$\mathrm{CO}$

$\mathrm{CO}_{2}$

$\mathrm{CH}_{4}$

(d)

273

274

Figure 4: Gas profiles at a ratio of throat to gasifier diameter of (a) 0.25 ; (b) 0.30 ; (c) 0.40 and (d) 0.50 at a fixed position of the air inlet nozzles at $10 \mathrm{~cm}$ above the throat

Table 2: Modelling gas composition at the outlet over various throat diameters at a fixed position of the air inlet nozzles at $10 \mathrm{~cm}$ above the throat

\begin{tabular}{|c|c|c|c|c|}
\hline \multirow{2}{*}{$\begin{array}{c}\text { Syngas } \\
\text { composition }\end{array}$} & \multicolumn{4}{|c|}{ Throat diameter, cm (ratio of throat to gasifier diameter) } \\
\cline { 2 - 5 }$(\%$ mol $)$ & $(0.25)$ & $(0.30)$ & $(0.40)$ & 10 \\
\hline $\mathrm{H}_{2}$ & 29.49 & 28.79 & 31.23 & 28.58 \\
\hline $\mathrm{CO}$ & 32.06 & 27.04 & 24.99 & 25.92 \\
\hline $\mathrm{CO}_{2}$ & 14.41 & 14.47 & 14.38 & 14.28 \\
\hline $\mathrm{CH}_{4}$ & 5.92 & 4.67 & 3.20 & 3.41 \\
\hline
\end{tabular}

As shown in Table 2, the throat diameter had a considerable effect on the $\mathrm{H}_{2} / \mathrm{CO}$ ratio and $\mathrm{CH}_{4}$ concentration, but little influence on the $\mathrm{CO}_{2}$ concentration in the syngas. The $\mathrm{H}_{2}$ 
concentration at the outlet $(31.2 \% \mathrm{~mol})$ maximised at a ratio of throat to gasifier diameter of 0.40 and decreased when increasing the ratio of throat to gasifier diameter. The concentration of $\mathrm{CO}_{2}$ remained almost constant around $14.4 \% \mathrm{~mol}$ with all tested throat to gasifier diameter ratios. However, $\mathrm{CH}_{4}$ concentration decreased from $5.90 \% \mathrm{~mol}$ to $3.41 \%$ mol when increasing the ratio of throat to gasifier diameter from 0.25 to 0.50 . The uniform temperature across the throat downdraft gasifier (Figure 6), favours the products of endothermic reactions, i.e. the Boudouard (R-4), water gas (R-5) and steam-reforming (R-7) reactions, resulting in an increased concentration of $\mathrm{H}_{2}$ and CO. Moreover, an increase in the steam-reforming reaction (R-7) also resulted in a decrease of $\mathrm{CH}_{4}$ concentration in the gas stream. The gas concentrations obtained from this study (Table 2) were slightly higher than other modelling studies [21, 24, 32, 51-53]. Previous downdraft gasifier are in the range of $13-25 \% \mathrm{~mol} \mathrm{H}_{2}, 18-38 \% \mathrm{~mol} \mathrm{CO}, 8-11 \% \mathrm{~mol} \mathrm{CO}_{2}$ and $1-3 \%$ mol of $\mathrm{CH}_{4}$. The differences were due to the assumptions, kinetic parameters, properties of feedstock and/or gasifier design.

Comparing to experimental data of a small scale throat downdraft gasifier [21, 29, 54, 55] (the designs and operating parameters were shown in Table 3), the trends of syngas composition and temperature profile was similar. As shown in Figure 5, the ratio of $\mathrm{H}_{2} / \mathrm{CO}$ increased from 0.56 to 0.86 when increasing the ratio of throat to gasifier diameter concentration. A reduction in the concentration of $\mathrm{CH}_{4}$ was observed when increasing the ratio of throat to gasifier diameter. The gas composition obtained from the modelling 
approximately $4.62 \%$ difference across the range. It is also noted that the concentration of syngas from this study was slightly higher than that obtained from experimental data.

307 This is because (i) the simulation model assumed that all the volatiles and tar compounds 308 in the pyrolysis zone were instantaneously decomposed into $\mathrm{CO}, \mathrm{CO}_{2}, \mathrm{CH}_{4}, \mathrm{H}_{2}$ and $\mathrm{H}_{2} \mathrm{O}$ 309 compounds, (ii) the simulation model leads to more effective gasification reactions, in terms of kinetic reaction rates compared to experimental, (iii) the equivalence ratio (ER) and the composition of biomass feedstock were used and (iv) no heat loss in the system was assumed, resulting in an increased proportion of components in the syngas product.

Table 3: The experimental designs and operating parameters of a throat downdraft gasifier

\begin{tabular}{|c|c|c|c|c|}
\hline & $\begin{array}{c}\text { Zainal } \\
\text { et al. [29] }\end{array}$ & $\begin{array}{l}\text { Chawdhury and } \\
\text { Mahkamov [54] }\end{array}$ & $\begin{array}{l}\text { Duleeka } \\
\text { et al. [55] }\end{array}$ & $\begin{array}{c}\text { Ozgun } \\
\text { and Mehmet } \\
\text { [21] }\end{array}$ \\
\hline $\begin{array}{l}\text { Fuel and } \\
\text { composition } \\
\text { (\%wt, dry } \\
\text { basis) }\end{array}$ & $\begin{array}{l}\text { Wood chip: } \\
\text { (47.3\% C; } \\
5.8 \% \mathrm{H} ; \\
46.1 \% \mathrm{O} ; \\
0.8 \% \mathrm{~N} \text { ) }\end{array}$ & $\begin{array}{l}\text { Wood chip: } \\
\text { (54.0\% C; } \\
6.0 \% \mathrm{H} ; \\
43.0 \% \mathrm{O})\end{array}$ & $\begin{array}{l}\text { Wood stick: } \\
\text { (48.6\% C; } \\
6.2 \% \mathrm{H} ; \\
44.87 \% \mathrm{O} ; \\
0.33 \% \mathrm{~N})\end{array}$ & $\begin{array}{c}\text { Wood pellets: } \\
\text { (50.67\% C; } \\
\text { 6.18\% H; } \\
41.15 \% \mathrm{O} ; \\
2 \% \mathrm{~N})\end{array}$ \\
\hline $\begin{array}{l}\text { Biomass feed } \\
\text { rate }\left(\mathrm{kghr}^{-1}\right)\end{array}$ & n.a. & 3.1 & 1.0 & $3.5-4.0$ \\
\hline $\begin{array}{l}\text { Particle } \\
\text { diameter }(\mathrm{cm})\end{array}$ & 5 & $3-7$ & 2.5 & 1 \\
\hline
\end{tabular}




\begin{tabular}{|l|c|c|c|c|}
\hline Gasifier & & & & \\
dimensions & $250 / 60$ & $91.7 / 21.9$ & $110 / 39$ & $55 / 28$ \\
\hline Th/Ø) (cm) & & & & \\
diameter (cm) & 20 & 8.8 & 17.5 & 7 \\
\hline Throat to & 0.33 & 0.40 & 0.45 & 0.25 \\
gasifier ratio & & & & 0.23 \\
\hline Equivalence & 0.27 & 0.35 & 0.36 & \\
ratio (ER) & & & & \\
\hline
\end{tabular}

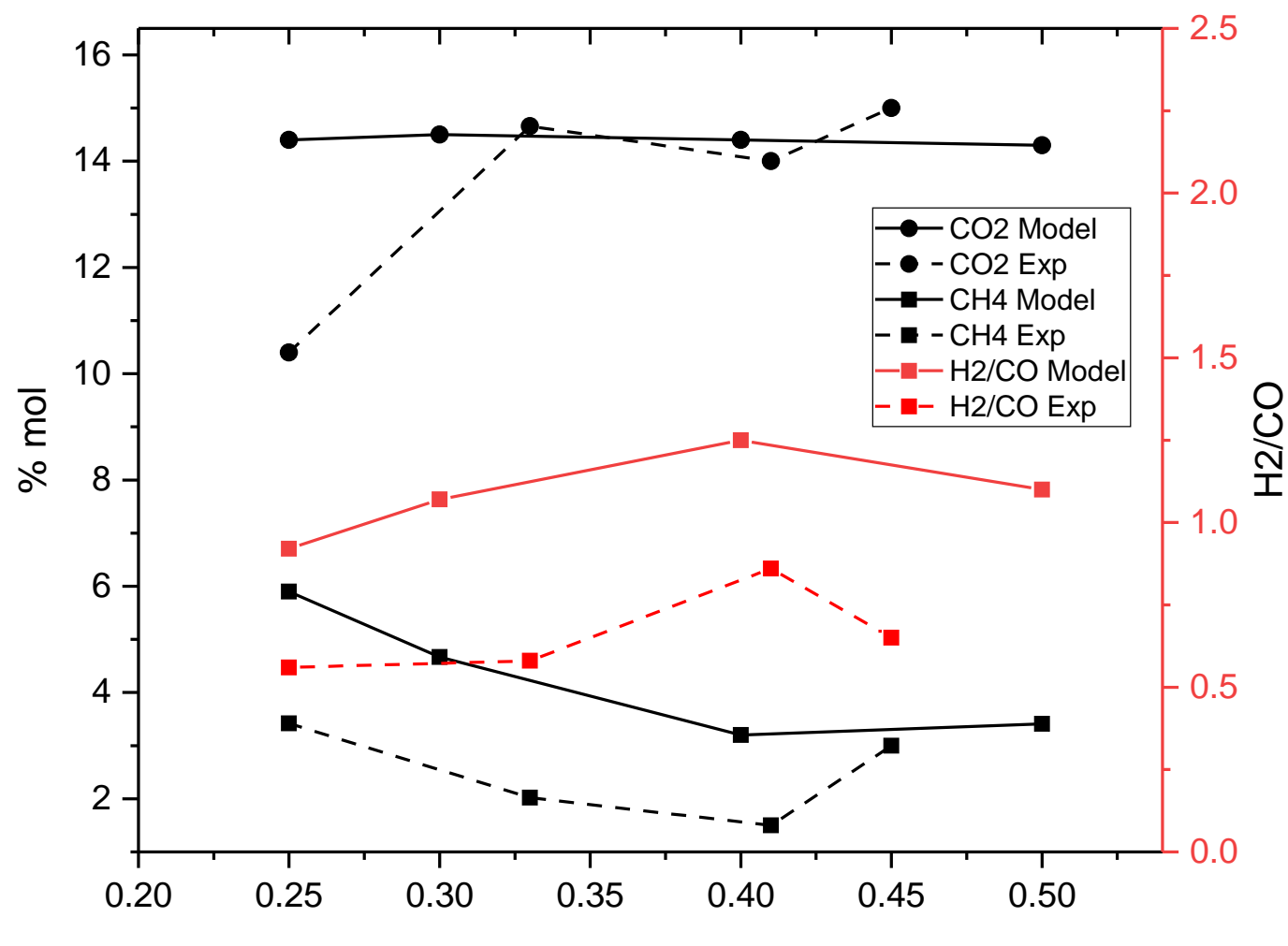

The ratio of throat to gasifier diameter

317 Figure 5: Comparison of modelling gas composition obtained from this study and experimental data derived from literature [21, 29, 54, 55]. 


\subsubsection{Temperature profile}

The temperature distribution across the throat downdraft gasifier over various throat diameters of 5, 6, 8 and $10 \mathrm{~cm}$, corresponding to the ratios of throat to gasifier diameter of $0.25-0.50$ at a fixed position of the air inlet nozzles of $10 \mathrm{~cm}$ above the throat are illustrated in Figure 6. It can be observed that between $10 \mathrm{~cm}$ and $25 \mathrm{~cm}$, corresponding to the pyrolysis zone (shown in Figure 2a), the temperature increased from $400 \mathrm{~K}$ to 1100 $\mathrm{K}$. This is due to the heat provided by the radiation from the oxidation zone (combustion of char), which is the hottest part of the throat downdraft gasifier $[8,50,56]$. However, no significant changes in the temperature distribution in the pyrolysis zone were observed under any of the tested throat diameters. The oxidation zone occurred at the height of 0 $\mathrm{cm}$ to $10 \mathrm{~cm}$ in the gasifier (Figure 2a). This is important as this is the region where the main reactions occur in the throat downdraft gasifier; in consequence the relationship between throat diameter, gasifier diameter and the position of the air inlet nozzles has an effect on the temperature distribution and the properties of the syngas. As shown in Figure 6, the high and uniform temperature of $2000 \mathrm{~K}$ across the oxidation zone was observed with a ratio of throat to gasifier diameter of 0.40 (Figure 6c) compared to at a ratio of 0.25 and 0.30 at $1800 \mathrm{~K}$ and 0.50 at $1600 \mathrm{~K}$. High and uniform temperature across the oxidation zone is important to eliminate tar formation in the gas stream $[7,57,58]$. The reduction zone at distance of $0 \mathrm{~cm}$ to $-30 \mathrm{~cm}$ (Figure 2a), had temperature in the range of 900-1000 K with all tested throat to gasifier diameter ratios. Syngas ( $\mathrm{H}_{2}$ and $\mathrm{CO}$ ) was produced in this region via the reactions R-4-8.

The trend of modelling temperature distribution in three different zones (pyrolysis, oxidation and reduction) agreed very well with experimental data derived from the literature [21, 29, 54, 55]: increasing from pyrolysis zone to oxidation zone and then 
343 decreasing gradually. The differences between the modelling temperature in the pyrolysis

344 and reduction zones and those obtained from experiments was less than $10 \%$. However,

345 the modelling temperature in the oxidation zone was up 36\% higher. This can be due to

346 (i) the assumption made in the model air was preheated at $350 \mathrm{~K}$ before introduction into

347 the gasifier through four nozzles, (ii) no heat loss in the system, (iii) rates of reactions

348 occurring in the oxidation zone and (iv) the ratio of the actual air/fuel to the stoichiometric

349 air/fuel (ER ratio) i.e. at high ER ratio leading to an increase in the gasification

350 temperature particularly in the oxidation zone $[10,59]$. High and uniform temperature

351 across the throat downdraft gasifier was obtained at a ratio of throat diameter to gasifier

352 diameter of 0.40 .

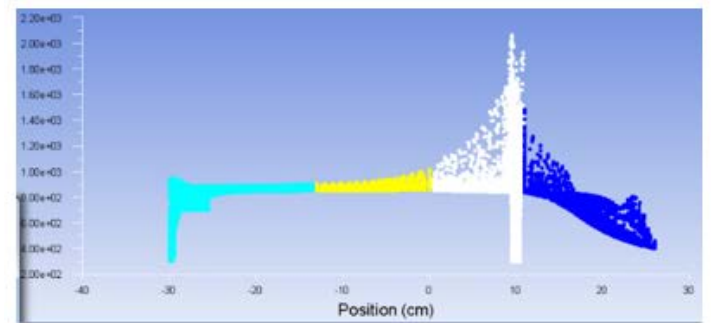

(a)

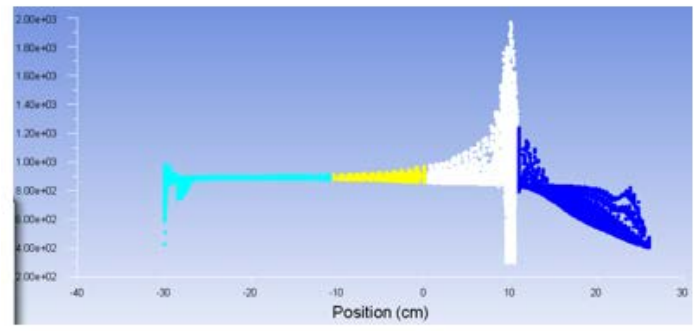

(c)

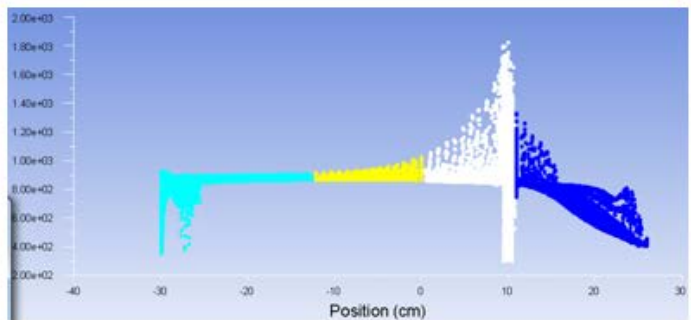

(b)

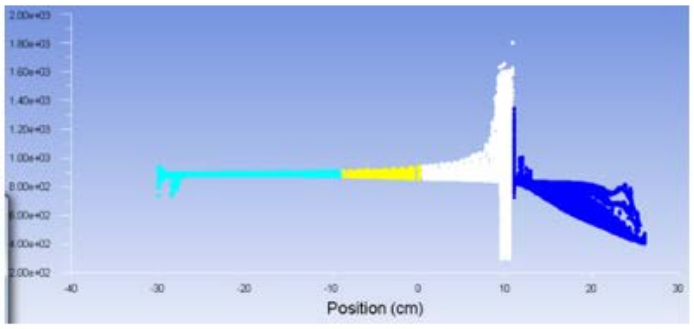

(d)

Figure 6: Temperature distribution at a ratio of throat to gasifier diameter of (a) 0.25 ; (b) throat 

validation

\subsubsection{Syngas composition}

The formation of the produced gas in a throat downdraft gasifier under various air inlet nozzles positions located at 8,10 and $12 \mathrm{~cm}$ above the throat at a fixed throat to gasifier diameter ratio of 0.40 are illustrated in Figure $7 . \mathrm{H}_{2}$ and $\mathrm{CO}$ concentrations were maximised in the reduction zone in the range of $27-31 \% \mathrm{~mol} \mathrm{H}_{2}$ and $23-27 \% \mathrm{~mol} \mathrm{CO}$, via the Boudouard (R-4), water gas (R-5) and steam-reforming (R-7) reactions. The $\mathrm{CO}_{2}$ concentration was low $(6-10 \% \mathrm{~mol})$ in the pyrolysis zone and maximised at $23-27 \% \mathrm{~mol}$ in the oxidation zone, due to the combustion of char (R-1) followed by a decrease to 14\%mol after passing through the reduction zone. A similar trend was observed with the $\mathrm{CH}_{4}$ concentration. As shown in Figure 7, the formation of syngas was more uniform across the throat downdraft gasifier at the position of the air inlet nozzles at $10 \mathrm{~cm}$ (Figure 7b) and $12 \mathrm{~cm}$ (Figure 7c) than at $8 \mathrm{~cm}$ above the throat (Figure 7a). When the air inlet nozzles were positioned at $8 \mathrm{~cm}$ above the throat, they sat at the beginning of the inclination of the throat, therefore cold spots may occur resulting in low and non-uniform temperature with poor mixing of the volatiles, char and gasifying agent (air) in the oxidation zone. A comparison of the main syngas compositions generated under the various air inlet nozzles positions above the throat at a fixed throat to gasifier diameter ratio is illustrated in Table 4. 


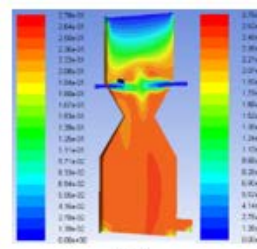

$\mathrm{H}_{2}$ $\mathrm{CO}$

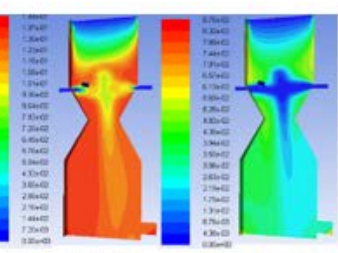

$\mathrm{CO}_{2}$
$\mathrm{CH}_{4}$

(a)

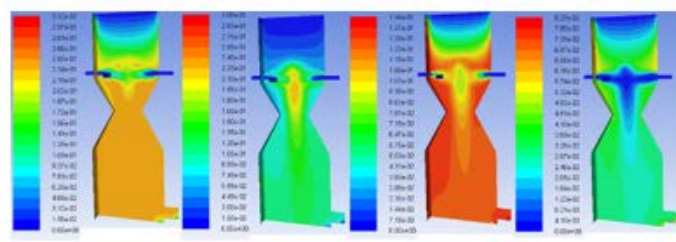

$\mathrm{H}_{2}$

$\mathrm{CO}_{2}$

$\mathrm{CH}_{4}$

(b)

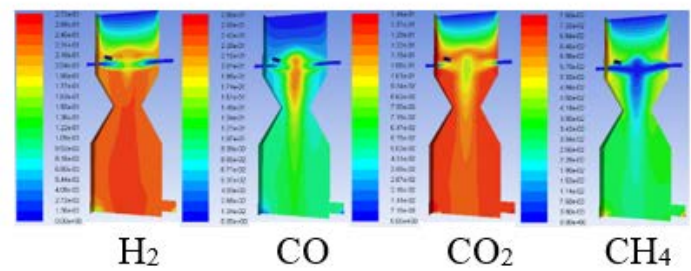

(c)

379 Figure 7: Gas profiles at the air inlet nozzles position at (a) $8 \mathrm{~cm}$; (b) $10 \mathrm{~cm}$ and (c) 12

$\mathrm{cm}$ above the throat at a fixed throat to gasifier diameter ratio of 0.40

381 Table 4: Gas composition at the outlet over various air inlet nozzles positions above the

382 throat at a fixed throat to gasifier diameter ratio of 0.40

\begin{tabular}{|c|c|c|c|}
\hline \multirow{2}{*}{$\begin{array}{c}\text { Syngas } \\
\text { composition } \\
(\% \text { mol })\end{array}$} & 8 & 10 & 12 \\
\cline { 2 - 4 } & 27.75 & 31.23 & 27.19 \\
\hline $\mathrm{H}_{2}$ & 27.59 & 24.99 & 23.83 \\
\hline $\mathrm{CO}$ & 14.39 & 14.38 & 14.44 \\
\hline $\mathrm{CO}_{2}$ & 3.75 & 3.20 & 2.59 \\
\hline $\mathrm{CH}_{4}$ & & & \\
\hline
\end{tabular}

It can be observed that the air inlet position had a significant effect on the concentration

of $\mathrm{H}_{2}$, $\mathrm{CO}$ and $\mathrm{CH}_{4}$, but no influence on the $\mathrm{CO}_{2}$ concentration. The ratio of $\mathrm{H}_{2} / \mathrm{CO}$

increased from 1.01 to 1.25 and decreased to 1.14 when increasing the air inlet nozzles 
the concentration of $\mathrm{CO}_{2}$ remained constant at $14.4 \%$ mol with all tested air inlet nozzles position. These results can be explained because increasing the height of the air inlet nozzles position above the throat results in a reduction in the length of the pyrolysis zone, therefore the formation of $\mathrm{CH}_{4}$ in this region was decreased. At the same time, increasing the length of the reduction zone results in an increase the reaction time (Reactions R-48), leading to an increases in concentrations of $\mathrm{H}_{2}$ and $\mathrm{CO}$ and a reduction of $\mathrm{CH}_{4}$ concentration. The maximised ratio of $\mathrm{H}_{2} / \mathrm{CO}$ obtained in this study (Table 4) were in good agreement with experimental data obtained in a small scale throat downdraft gasifier at a fixed position of the air inlet nozzles at $10 \mathrm{~cm}$ above the throat [60-62]. However, the experimental results obtained from Wim et al. [63] showed that the ratio of $\mathrm{H}_{2} / \mathrm{CO}$ was maximised at the position of the air inlet nozzles at $12.5 \mathrm{~cm}$ above the throat for a small scale throat downdraft gasifier. It is known that the ratio of $\mathrm{H}_{2} / \mathrm{CO}$ in the syngas has a significant impact on its utilization i.e. $\mathrm{H}_{2} / \mathrm{CO} \leq 1$ is suitable for heating and power generation in a small-scale heat engines $(<2 \mathrm{MW})$ while the ratio of $\mathrm{H}_{2} / \mathrm{CO}>1$ can be used in the production of fuel or for chemical synthesis [64-66]. From Table 4, it can be concluded that high quality syngas with a high ratio of $\mathrm{H}_{2} / \mathrm{CO}$ at 1.25 and low concentrations of $\mathrm{CO}_{2}$ and $\mathrm{CH}_{4}$ in the gas stream was obtained at the position of the air inlet nozzles at $10 \mathrm{~cm}$ above the throat.

\subsubsection{Temperature profile}

The temperature distribution across the throat downdraft gasifier under various air inlet nozzles positions located at 8,10 and $12 \mathrm{~cm}$ above the throat at a fixed throat to gasifier diameter ratio of 0.40 is illustrated in Figure 8 . The position of the air inlet nozzles had no significant effect on the temperature distribution in the pyrolysis and reduction zones. However, the temperature was more uniform across the oxidation zone at a position of 10 
and $12 \mathrm{~cm}$ (Figure $8 \mathrm{~b}$ and $8 \mathrm{c}$ ) than $8 \mathrm{~cm}$ above the throat (Figure 8a). This is because the position of the air inlet nozzles at $8 \mathrm{~cm}$ above the throat was located at the inclination of the throat, causing cold spots in the oxidation zone, therefore resulting in low and nonuniform temperature. Low and non-uniform temperature in the oxidation zone $(<1273$ K) leads to a considerable amount of large molecular weight species (tar) in the gas stream $[14,17,27,67,68]$. If the rapid released of volatiles from the pyrolysis zone and gasifying agent are not well-mixed with gasifying agent and the temperature is not high enough for the cracking of tar compounds, there are difficulties for the downstream process such as corrosion, clogging and fouling of the installation. [15, 16].

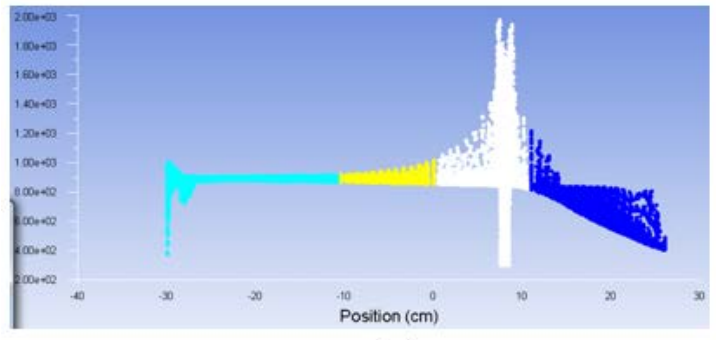

(a)

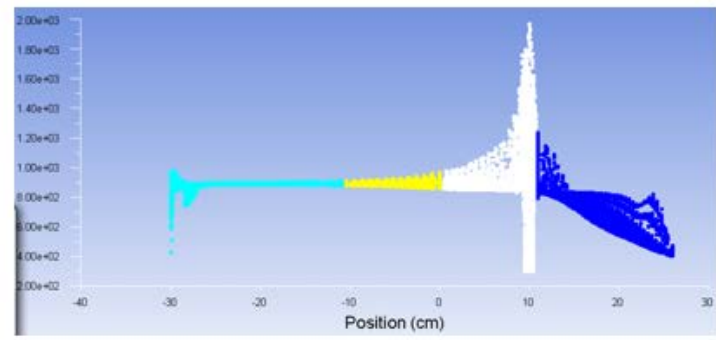

(b)

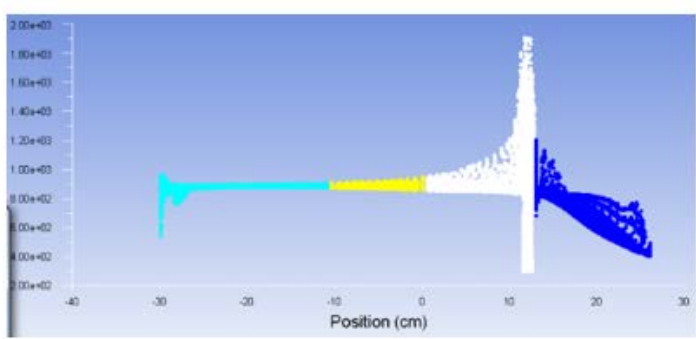

(c)

Figure 8: Temperature distribution at the air inlet nozzles position at (a) $8 \mathrm{~cm}$; (b) $10 \mathrm{~cm}$ and (c) $12 \mathrm{~cm}$ above the throat at a fixed throat to gasifier diameter ratio of 0.40

\section{Conclusions}

A $20 \mathrm{~cm}$ diameter throat downdraft gasifier was designed and numerically optimised using the Computational Fluid Dynamic (CFD), ANSYS FLUENT 16.1. The produced gas composition and temperature distribution across the throat downdraft gasifier were 
predicted and validated over various ratios of throat to gasifier diameter of $0.25-0.50$ and the positions of the air inlet nozzles at 8,10 and $12 \mathrm{~cm}$ above the throat. The modelling results showed that throat to gasifier diameter ratios and the position of the air inlet nozzles had a significant effect on the syngas formation, properties of gas and temperature distribution particularly in the oxidation zone. Increasing a ratio of throat to gasifier diameter decreased $\mathrm{CH}_{4}$ concentration but had no effect on $\mathrm{CO}_{2}$ formation. The highest concentration of $\mathrm{H}_{2}$ and $\mathrm{H}_{2} / \mathrm{CO}$ ratio $(31.2 \% \mathrm{~mol})$ at the ratio of $\mathrm{H}_{2} / \mathrm{CO}$ (1.25) was obtained at a throat to gasifier diameter ratio of 0.40 . Increasing further the ratio of throat to gasifier diameter caused a reduction in hydrogen or ratio of $\mathrm{H}_{2} / \mathrm{CO}$. Increasing the air inlet position from $8 \mathrm{~cm}$ to $10 \mathrm{~cm}$ above the throat increased the ratio of $\mathrm{H}_{2} / \mathrm{CO}$ from 1.01 to 1.25. A further increase in the air inlet nozzle caused a reduction of $\mathrm{H}_{2} / \mathrm{CO}$ to 1.14. A $31 \%$ reduction in the concentration of $\mathrm{CH}_{4}$ was observed when increasing the air inlet nozzles from $8 \mathrm{~cm}$ to $12 \mathrm{~cm}$ above the throat.

A very good agreement between experimental and modelling data was observed, with less than 5\% difference. The trend in temperature distribution in the gasifier obtained from the modelling was also in good agreement with experimental data. High and uniform temperature across the oxidation zone was also obtained at a throat to gasifier diameter ratio of 0.40 . Therefore, the mathematical approach in this study can be used as a design and optimisation tools for a throat downdraft biomass gasifier to achieve high quality of biomass feedstock, the equivalence ratio (ER).

450 


\section{References}

453 [1] International Energy Outlook 2016 (IEO2016). International Energy Outlook 2016 454 with Projections to 2040, U.S. Energy Information Administration, DOE/EIA-0484, 455 Washington, DC, 2016.

456 [2] International Energy Agency 2015 (IEA2015). Would Energy Outlook 2015, 457 OECD/IEA, Paris, 2015.

458 [3] International Energy Agency (2000). World Energy Outlook 2000, IEA, Paris, 2000.

459 [4] IEA Bioenergy (2009). Bioenergy - a Sustainable and Reliable Energy Source - A 460 Review of Status and Prospects (EXCO: 2009: 06).

461 [5] IEA Bioenergy (2015). Annual Report 2015 (EXCO: 2016: 0.1).

462 [6] Abhishek Sharma, Vishnu Pareek and Donke Zhang (2015). Biomass pyrolysis - A 463 review of modelling, process parameters and catalytic studies. Renewable and 464 Sustainable Energy Reviews, Volume 50, Pages 1081-1096.

465 [7] Ruiz, J.A., Juarez, M.C., Morales, M.P., Munoz, P. and Mendivil, M.A. (2013). 466 Biomass gasification for electricity generation: Review of current technology barriers. 467 Renewable and Sustainable Energy, Volume 18, Pages 174-183.

468 [8] Maria Puig-Arnavat, Joan Carles Vruno and Alberto Coronas (2010). Review and 469 analysis of biomass gasification models. Renewable and Sustainable Energy Reviews, 470 Volume 14, Issue 9, Pages 2841-2851.

471 [9] Aly Moustafa Radwan (2012). An overview on gasification of biomass for production 472 of hydrogen rich gas. Pelagia Research Library, Volume 3, Pages 323-335.

473 [10] Yashwant Kumar (2015). Biomass gasification - A review. International Journal of 474 Engineering Studies and Technical Approach, Volume 1, Pages 12-27. 
475 [11] Frederic Fabry, Christophe Rehmet, Vandad-Julien Rohani and Laurent Fulcheri 476 (2013). Waste Gasification by Thermal Plasma: A Review. Waste and Biomass 477 Valorization, Volume 4, Issue 3, Pages 421-439.

478 [12] Li C. and Suzuki K. (2009). Tar property, analysis, reforming mechanism and model 479 for biomass gasification- An overview. Renewable and Sustainable Energy Review, 480 volume 13, Pages 594-604.

[13] Morf P. (2001) Secondary reactions of tar during thermochemical biomass conversion. PhD thesis. Swiss Federal Institute of Technology, Zurich.

[14] Milne T., Evans R. and Abatzoglou (1998). Biomass Gasifier “Tars”: Their Nature, Formation and Conversion. National Renewable Energy Laboratory.

[15] Umberto Arena (2012). Process and technological aspects of municipal solid waste gasification. A review. Waste Management, Volume 32, Issue 4, Pages 625-639.

[16] Linghong Zhang, Chunbao Xu and Pascale Champagne (2010). Overview of recent advances in thermos-chemical conversion of biomass. Energy Conversion and Management, Volume 51, Issue 5, Pages 969-982.

[17] Shanhui Zhao, Yi Su, Wenguang Wu, Yunliang Zhange, Yuu Wang and Yonghao Luo (2013). Numerical Simulation of Partial Combustion for Biomass Tar Elimination in Two-Stage Gasifier. Journal of Sustainable Bioenergy Systems, Volume 3, Pages 86-92. [18] Xinging Lan, Hanbin Zhong and Jinsen Gao (2014). CFD simulation on the gasification of asphalt water slurry in an entrained flow gasifier. Petroleum Science, 495 Volume 11, Issue 2, Pages 308-317.

[19] Pubet Meenaroch, Somrat Kerdsuwan and Krongkaew Laohalidanond (2015). 
499 [20] Ashish Chaurasia (2016). Modeling, simulation and optimization of downdraft 500 gasifier: Studies on chemical kinetics and operating conditions on the performance of the 501 biomass gasification process. Energy, Volume 116, Part 1, Pages 1065-1076.

502 [21] Ozgun Yucel and Mehmet Alaittin Hastaoglu (2016). Kinetic modelling and 503 simulation of throat downdraft gasifier. Fuel Processing Technology, Volume 144, Pages $504 \quad 145-154$.

505 [22] Nuno Couto, Valter Silva, Eliseu Monteiro, Paulo Brito and Abel Rouboa (2015). 506 Using an Eulerian-granular 2-D multiphase CFD model to simulate oxygen air enriched 507 gasification of agroindustrial residues. Renewable Energy, Volume 77, Pages174-181.

508 [23] Dejtrakulwong C. and Patumsawad S. (2014). Four Zones modelling of the 509 Downdraft Biomass Gasification Process: Effect of Moisture Content and Air to Fuel 510 ratio. Energy Procedia, Volume 52, Pages 142-149.

511 [24] Yueshi Wu, Qinglin Zhang, Weihong Yang and Wlodzimierz Blasiak (2013). Two512 Dimensional Computational Fluid Dynamics Simulation of Biomass Gasification in a 513 Downdraft Fixed-Bed Gasifier with Highly Preheated Air and Steam. Energy and Fuels, 514 Volume 27, Pages 3274-3282.

515 [25] Keran D. Patel, N.K. Shah and R.N, Patel (2013). CFD Analysis of Spatial 516 Distribution of Various Parameters in Downdraft Gasifier. Procedia Engineering, Volume 517 51, Pages 764-769.

518 [26] Muilenburg M. (2011). Computational modelling of the combustion and gasification 519 zones in a downdraft gasifier. Master Thesis lowa University.

520 [27] Luc Gerun, Maria Paraschiv, Razvan Vijeu, Jerome Bellettre, Mohand Tazerout, 521 Benny Gobel and Ulrik Henriksen (2008). Numerical investigation of the partial 522 oxidation in a two-stage downdraft gasifier. Fuel, Volume 87, Issue 7, Pages 1383-1393. 
523 [28] Rogel A. and Aguillon J. (2006). The 2D Eulerian Approach of Entrained Flow and 524 Temperature in a Biomass Stratified Downdraft Gasifier. American Journal of Applied 525 Sciences, Volume 3, Pages 2068-2078.

526 [29] Zainal Z.A., Ali Rifau, Quadir and Seetharamu K.N. (2002). Experimental 527 investigation of a downdraft biomass gasifier. Biomass and Bioenergy, Volume 23, Pages $528 \quad 283-289$.

529 [30] Sivakumar S., Pitchandi K. and Natarajan E. (2006). Design and Analysis of 530 DownDraft Biomass Gasifier using Computational Fluid Dynamics. Department of 531 Mechanical Engineering, College of Engineering, Guindy, Anna, INDIA.

532 [31] Rivi Kumar, Narendhar Baba, Suresh Kumar and Venkata Vishnu (2016). CFD 533 Simulation of Down Draft Biomass Gasifier. International Journal of Advance 534 Engineering and Research, Volume 3, Issue 1.

535 [32] Jayah T.H., Lu Aye, Fuller R.J. and Stewart D.F. (2003). Computer simulation of a 536 downdraft wood gasifier for tea drying. Biomass and Bioenergy, Volume 25, Pages 459537469.

538 [33] Sivakumar S., Pitchandi K. and Natarajan E. (2008). Modelling and simulation of 539 down draft wood gasifier. Journal of Applied Science, Volume 8, Issue 2, Page 271-279. 540 [34] Dziyad Dzulfansyah, Leopold Oscar Nelwan and Dyah Wulandani (2014). 541 Computational Fluid Dynamic Analysis for Desiging Downdraft-Rice Hush Gasifier. 542 Journal Keteknikan Pertanian, Volume 2, Pages 133-140.

543 [35] Gerber S., Behrendt F. and Oevermann M. (2010). An Eulerian modelling approach 544 of wood gasification in a bubbling fluidized bed reactor using char as bed material. Fuel, 545 Volume 89, Pages 2903-2917. 
546 [36] Haojie Fan, Dengfei Mei, Fengguo Tian, Xuan Cui and Mingchuan Zhang (2016).

547 DEM simulation of different particle ejection mechanisms in a fluidized bed with and

548 without cohesive interparticle forces. Powder Technology, Volume 288, Pages 228-240.

549 [37] Xiaofang Wang, Baosheng Jin and Wenqi Zhong (2009). Three-dimensional

550 simulation of fluidized bed coal gasification. Chemical Engineering and Processing:

551 Process Intensification, Volume 48, Pages 695-705.

552 [38] Yuqing Feng, Tim Swenser-Smith, Peter J. Witt, Christian Doblin, Seng Lim and M.

553 Phil Schwarz (2012). CFD modelling of gas-solid flow in an internally circulating

554 fluidized bed. Powder Technology, Volume 219, Pages 78-85.

555 [39] Xiaoke Ku, Tian Li and Terese Lovas (2015). CFD-DEM simulation of biomass

556 gasification with steam in a fluidized bed reactor. Chemical Engineering Science, Volume 557 122, Pages 270-283.

558 [40] Liang Lu, T.M. Ismail, Yuqi Jin, M. Abd EI-Salam and Kunio Yoshikawa (2016).

559 Numerical and experimental investigation on co-combustion characteristics of 560 hydrothermally treated municipal solid waste with coal in a fluidized bed. Fuel Processing 561 Technology, Volume 154, Pages 52-65.

562 [41] Shafie S.M., Mahlia T.M.I., Masjuki H.H. and Ahmad-Yazid A. (2012). A review 563 on electricity generation bases on biomass residue in Malaysia. Renewable and 564 Sustainable Energy Reviews, Volume 16, Issue 8, Pages 5879-5889.

565 [42] Niranjan Fernando and Mahinsasa Narayana (2016). A comprehensive two 566 dimensional Computational Fluid Dynamics model for an updraft biomass gasifier. 567 Renewable Energy, Volume 99, Pages 698-710. 
[43] Wahab Mojtahedi, Matti Ylitalo, Teuvo Maunula and Javad Abbasian (1995).

Catalytic decomposition of ammonia in fuel gas produced in pilot-scale pressurized fluidized-bed gasifier. Fuel Processing Technology, Volume 45, Issue 3, Pages 211-236. [44] Pekka Simell, Esa Kurkela, Pekka Stahlberg and Jouko Hepola (1996). Catalytic hot 572 gas cleaning of gasification gas, Catalysis Today, Volume 27, Issues 1-2, Pages 55-62.

573 [45] Lopamudra Devi, Krzysztof J. Ptasinski and Frans J.J.G. Jamssen (2003). A review 574 of the primary measures for tar elimination in biomass gasification processes. Biomass and Bioenergy, Volume 24, Issue 2, Pages 125-140. [46] Colomba Di Blasi (2000). Dynamic behaviour of stratified downdraft gasifier.

577 Chemical Engineering Science, Volume 55, Pages 2931-2944.

578 [47] Colomba Di Blasi (2008). Modeling chemical and physical processes of wood and 579 biomass pyrolysis. Progress in Energy and Combustion Science, Volume 34, Pages 47580 90.

581 [48] Fernando N., Amin M., Narayana M., Jayawickrama T. and Jayasena S. (2015). A 582 mathematical model for pyrolysis of biomass. Moratuwa Eng. Res. Conf. (MERCon), 583 IEEE Conference 2015.

[49] Chan WR, Kelbon M and Krieger BB (1985). Modeling and experimental 585 verification of physical and chemical processes during pyrolysis of large biomass particle. Fuel, Volume 64, Pages 1505-1513.

587 [50] Prabir Basu (2010). Gasification theory and modelling of gasifiers. In: Biomass 588 Gasification design Handbook. Academic Press, Boston.

589 [51] Marco Simone, Cristiano Nicolella and Leonardo Tognotti (2013). Numerical and 590 experimental investigation of downdraft gasification of woody residues. Bioresource 591 Technology, Volume 133, Pages 92-101. 
592 [52] Janajreh I. and Al Shrah M. (2013). Numerical and experimental investigation of 593 downdraft gasification of wood chips. Energy Conversion and Management, Volume 65, 594 Pages 783-792.

595 [53] Yueshi Wu, Weihong Yang and Wlodzimierz Blasiak (2014). Energy and Exergy 596 Analysis of High Temperature Agent Gasification of Biomass. Energies, Volume 7, Pages $597 \quad 2107-2122$.

598 [54] Chawdhury M.A. and Mahkamov K. (2011). Development of a Small Downdraft 599 Biomass Gasifier for Developing Countries. Journal of Scientific Research, Volume 3, 600 Pages 51-64.

601 [55] Duleeka Gunarathne, Sumudu Sajeewareka Jatunarachchi, Nihal srikantha 602 Senanayake and Bo Wei (2013). The effect of Throat Diameter on the Performance a 603 Downdraft Biomass Gasifier. International Journal of Energy Engineering, Volume3, 604 Pages 171-175.

605 [56] Kinoshita C. Turn S., Overend R. and Bain R. (1997). Power generation potential of 606 biomass gasification systems. Journal of Energy Engineering, Volume 123, Issue 3, Pages $607 \quad 88-99$.

608 [57] Rolando Zanzi, Krister Sjostrom and Emilia Bjornbom (2002). Rapid pyrolysis of 609 agricultural residues at high temperature. Biomass and Bioenergy, Volume 23, Issue 5, 610 Pages 357-366.

611 [58] Pfeifer C., Rauch R. and Hofbauer H. (2004). In-Bed Catalytic Tar reduction in a 612 Dual Fluidized Bed Biomass steam Gasifier. Industrial and Engineering Chemistry 613 Research, Volume 43, Issue 7, Pages 1634-1640. 
614 [59] Chuang-zhi Wu, Xiu-li Yin, Long-long Ma, Zhao-qiu Zhou and Han-ping Chen 615 (2009). Operational characteristics of a 1.2-MW biomass gasification and power 616 generation plant. Biotechnology Advances, Volume 27, Pages 588-592.

617 [60] Jan Venselaar (1982). Design rules for down draft wood gasifiers - A short review. 618 Project JTA-9A - Research Development at Institute Technology Bandung, Indonesia. 619 [61] FAO (1986). Wood gas as engine fuel. FAO Forestry Paper 72, Rome, Italy (UN620 FAO Forestry Department).

621 [62] Adenike A. Kolawole, S.B. Adeyemo and Moradeyo K. Odunfa (2013). Design and 622 Construction of Wood Gasifier, Mechanical Engineering Department, University of 623 Ibadan,Nigeria,http://www.academia.edu/7724922/design_and_construction_of_wood_ 624 gasifier [accessed 13.01.17].

625 [63] Wim P.M. van Swaaij, Sascha R.A. Kersten and Wolfgang Palz (2015). 626 Transformations to Effective Use Biomass Power for the World. Pan Stanford Series on 627 Renewable Energy Volume 6. In: Biomass Gasification System for small-Scale Power 628 Generation: Design Rules and Considerations for Systems Including the Down-Draft 629 Gasifier.

630 [64] Yung M.M., Jablonski W.S. and Magrini-Bair K.A. (2009). Review of Catalytic 631 Condition of biomass-Derived Syngas. Energy and Fuels, Volume 23, Issue 4, Pages $632 \quad 1874-1887$.

633 [65] Torres W., Pansare S. and Goodwin J. (2007). Hot gas removal of tars, ammonia and 634 hydrogen sulphide from biomass gasification tars. Catalysis Reviews, Volume 49, Pages 635 407-456. 
636 [66] Chaudhari S.T., Bej S.K., Bakhshi N.N. and Dalai A.K. (2001). Steam gasification 637 of biomass-derived char for the production of carbon monoxide-rich synthesis gas. 638 Energy and Fuel, Volume 15, Pages 736-742.

639 [67] McKendry P. (2002). Energy production from biomass (part 3): Overview of 640 biomass. Bioresource Technology, Volume 83, Pages 55-63.

641 [68] Morf P., Hasler P. and Nussbaumer T. (2002). Mechanisms and kinetics of 642 homogeneous secondary reactions of tar from continuous pyrolysis of wood chips, Fuel, 643 Volume 81, Pages 843-853. 